\title{
Analiza pracy wspornikowej belki kompozytowej z uwzględnieniem różnej grubości i lokalizacji spoiny klejowej wykonanej z materiału sprężysto-idealnie plastycznego
}

\author{
Bartosz Kawecki, Jerzy Podgórski \\ Katedra Mechaniki Budowli, Wydział Budownictwa i Architektury, Politechnika Lubelska, \\ e-mail: b.kawecki@pollub.pl,j.podgorski@pollub.pl
}

Streszczenie: W pracy przedstawiono wyniki analiz numerycznych wspornikowej belki kompozytowej ze spoiną z materiału sprężysto-idealnie plastycznego. Wykonano cztery modele numeryczne wykorzystujące Metodę Elementów Skończonych dla dwóch różnych grubości i lokalizacji spoiny klejowej. Wyznaczono przebieg uplastycznienia spoiny oraz wpływ jej grubości i lokalizacji w przekroju na naprężenia i przemieszczenia swobodnego końca belki.

Słowa kluczowe: Belka kompozytowa, uplastycznienie spoiny, przebieg uplastycznienia spoiny, wpływ grubości spoiny, wpływ lokalizacji spoiny na rozkład naprężeń.

\section{Wstęp}

Celem artykułu jest dokonanie wstępnej analizy pracy belek kompozytowych łączonych przy użyciu kleju o charakterystyce sprężysto-idealnie plastycznej. Producenci klejów często podają $\mathrm{w}$ kartach technicznych maksymalne dopuszczalne grubości spoin, które można wykonywać z wykorzystaniem ich produktów. Dlatego też istotne wydaje się być określenie sposobu pracy spoiny o różnej grubości, charakterystyce materiałowej i lokalizacji w przekroju, w celu późniejszego podania wytycznych do ich projektowania.

Analiza połączeń belek klejowych jest ciągle aktualnym tematem badań (por. $[1,4,5,11])$, których wyniki są ważne w zastosowaniach praktycznych. Wykorzystywany w tych analizach jest zwykle model pracy spoiny zaproponowany w 1938 roku przez Olafa Volkersena [12], który zakłada, że tylko naprężenia styczne mają wpływ na stan pracy spoiny. Przegląd różnych modeli spoin wykorzystywanych w modelach belek 1D i 2D można znaleźć w pracy Rodrígueza i inn. [11]. W pracy wykorzystano metodę elementów skończonych (MES) i sprężysto - idealnie plastyczny model materiału spoiny. Granicę przejścia materiału spoiny w stan plastyczny określa kryterium Hubera-Misesa. Obliczenia wykonano wykorzystując system MES - Symulation Mechanical (dawniej Algor) firmy Autodesk.

\section{Podstawy teoretyczne}

Na początek rozważmy teoretyczną pracę belki wspornikowej o długości $L$ i jednorodnym przekroju prostokątnym o wymiarach $b \times h$, obciążoną pionową siłą $T$, pracującą w zakresie liniowo-sprężystym. 

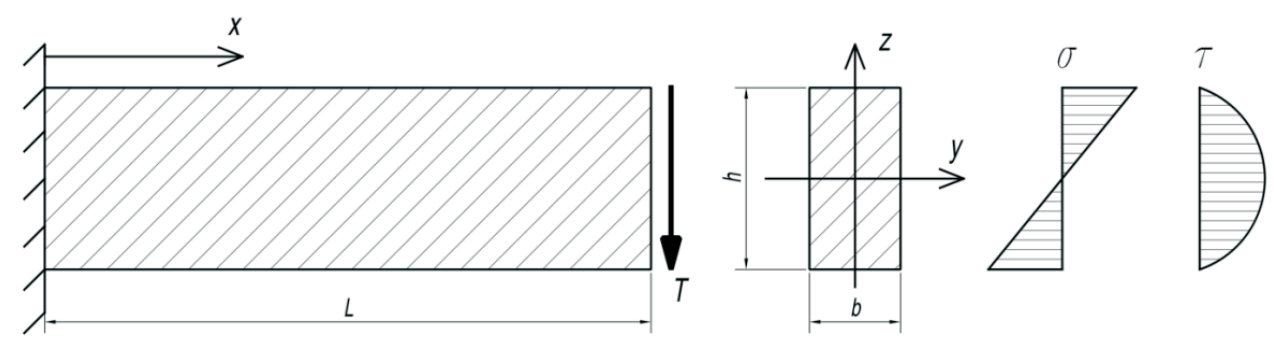

Rys. 1. Schemat belki wspornikowej o jednorodnym przekroju

Naprężenia zredukowane wg hipotezy Hubera-Misesa [3] w prostokątnym przekroju jednorodnym możemy wyznaczyć korzystając z następującego związku:

$$
\sigma_{\text {red }}(x, z)=\sqrt{\sigma(x, z)^{2}+3 \tau(x, z)^{2}}
$$

Przyjmując hipotezę płaskiego przekroju (Bernoulliego-Naviera, por. [3]), naprężenia normalne przy zginaniu można wyznaczyć na podstawie znanego równania:

$$
\sigma(x, z)=\frac{M(x) z}{J_{y}} .
$$

Moment zginający w przekroju opisany jest w rozważanym przykładzie zależnością:

$$
M(x)=T L\left(1-\frac{x}{L}\right),
$$

gdzie $J_{y}$ oznacza moment bezwładności przekroju poprzecznego belki.

Następnym krokiem jest określenie funkcji naprężeń normalnych z uwzględnieniem wymiarów przekroju oraz współrzędnych punktu, w którym będą wyznaczane naprężenia. Podstawiając odpowiednie wartości do wzoru (2) otrzymuje się następującą zależność:

$$
\sigma(x, z)=\frac{12 T L}{b h^{3}}\left(1-\frac{x}{L}\right) z
$$

Mając wyznaczoną funkcję naprężeń normalnych można przejść do wyznaczenia funkcji naprężeń stycznych, które opisać można następującym równaniem:

$$
\tau(x, z)=\frac{T S_{y}}{J_{y} b},
$$

gdzie $S_{y}$ oznacza moment statyczny wyznaczony względem osi $y$, tej części przekroju poprzecznego belki, która leży powyżej punktu o współrzędnej $z$.

Podstawiając odpowiednie wartości i przekształcając wzór (5) otrzymuje się następującą funkcję opisującą rozkład naprężeń stycznych:

$$
\tau(x, z)=\frac{3}{2} \frac{T}{b h}\left[1-4\left(\frac{z}{h}\right)^{2}\right]
$$

Po wyznaczeniu funkcji naprężeń normalnych (4) i stycznych (6) oraz podstawieniu ich do wzoru na naprężenia zredukowane (1) ostatecznie otrzymujemy: 


$$
\sigma_{\text {red }}(\xi, \zeta)=12 \frac{T}{A} \sqrt{[\lambda(1-\xi) \zeta]^{2}+\frac{3}{64}\left(1-4 \zeta^{2}\right)^{2}}
$$

gdzie $\xi i \zeta$ są bezwymiarowymi współrzędnymi punktu, w którym określamy wytężenie, $\lambda$ parametrem określającym smukłość belki, czyli stosunek jej długości do wysokości przekroju, $A$ oznacza tu pole powierzchni przekroju poprzecznego:

$$
\xi(x)=\frac{x}{L}, \quad \zeta(z)=\frac{z}{h}, \quad \lambda=\frac{L}{h} \quad A=b h .
$$

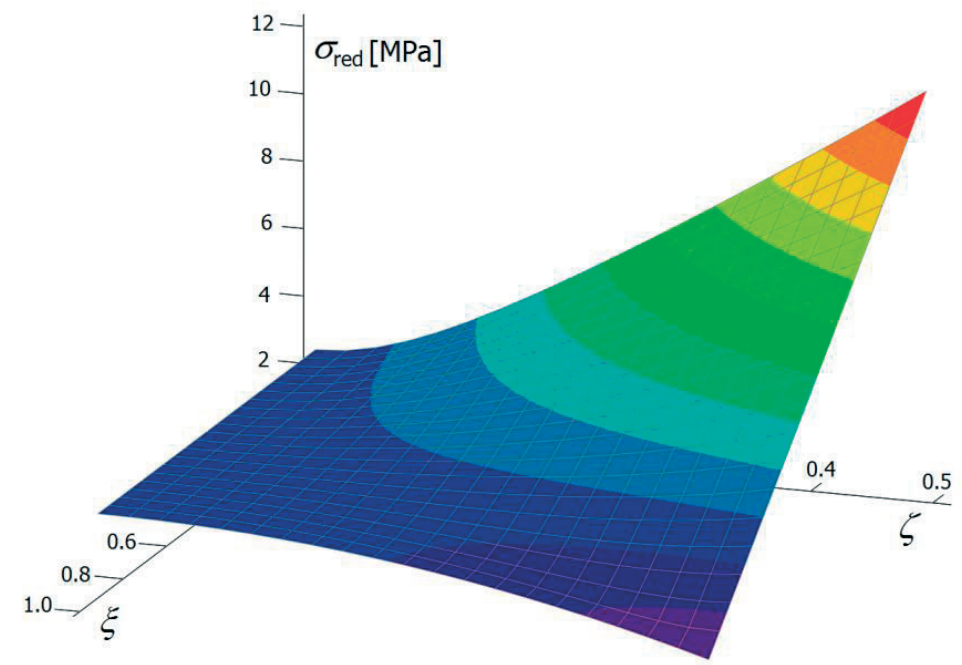

Rys. 2. Wykres funkcji $\sigma_{\text {red }}$ (równ. 7) dla $\lambda=2, T / A=1 \mathrm{MPa}$

Równanie to umożliwia wyznaczenie wartości naprężeń zredukowanych w dowolnym punkcie belki, co będzie potrzebne przy porównaniu tych wartości z naprężeniami otrzymanymi metodą numeryczną opisaną w następnym rozdziale pracy. Wyznaczane będą wartości naprężeń zredukowanych w 1/2 oraz w 1/4 wysokości przekroju, mierząc od góry. $\mathrm{Z}$ uwagi na to, że w kolejnym rozdziale prowadzona będzie analiza nieliniowa, do wzoru (7) na naprężenia zredukowane podstawiono siłę poprzeczną zależną od kroku czasowego i oznaczono ją przez $T=T(\Delta)$. Do dalszych obliczeń założono następujące parametry przekroju:

- $\quad$ szerokość przekroju $\rightarrow b=0,10 \mathrm{~m}$

- wysokość przekroju $\rightarrow h=0,20 \mathrm{~m}$

- długość belki $\rightarrow L=1,00 \mathrm{~m} \rightarrow \lambda=5$

- wyznaczenie naprężeń w $1 / 2$ wysokości belki $\rightarrow z=0,00 \mathrm{~m} \rightarrow \zeta=0$

- wyznaczenie naprężeń w $1 / 4$ wysokości belki $\rightarrow z=0,05 \mathrm{~m} \rightarrow \zeta=0,25$

$\mathrm{Na}$ podstawie wzoru (7) oraz przedstawionych danych, po uproszczeniu, wzory do wyznaczenia naprężeń zredukowanych będą wyglądały w następujący sposób:

- dla $1 / 2$ wysokości belki $(\zeta=0)$ :

$$
\sigma_{r e d}(\xi, \Delta)=\frac{3 \sqrt{3}}{2} \frac{T(\Delta)}{A}
$$


- dla $1 / 4$ wysokości belki $(\zeta=0,25)$ :

$$
\sigma_{\text {red }}(\xi, \Delta)=\frac{3 T(\Delta)}{A} \sqrt{25(1-\xi)^{2}+\frac{27}{64}}
$$

Korzystając z powyższych wzorów sporządzone zostały wykresy powierzchniowe obrazujące rozkład naprężeń w przekroju w zależności od przyrostu siły $T$ i długości belki, które przedstawiono na Rys. 3.

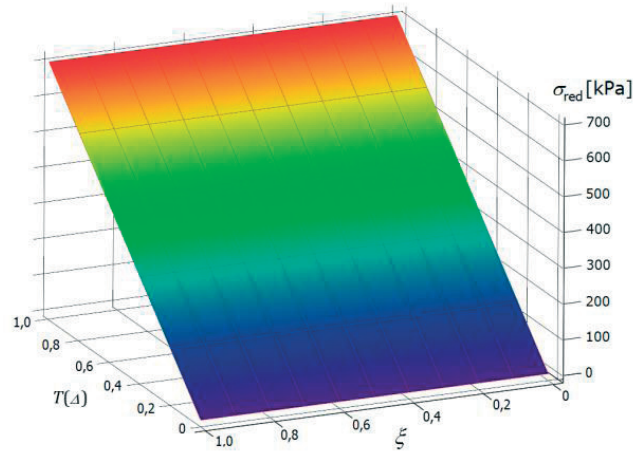

a) $\zeta=0$

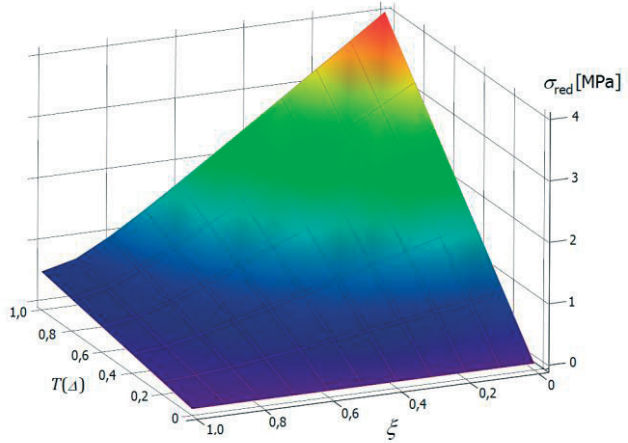

b) $\zeta=0.25$

Rys. 3. Wykresy naprężeń zredukowanych a) - obliczonych na podstawie równania (9) i b) - równania (10)

W kolejnym rozdziale rozpatrzone zostaną dwa przypadki usytuowania spoiny klejowej łączącej dwa elementy o takich samych parametrach. Z powyższych założeń teoretycznych wynika, że w przypadku ustawienia spoiny w $1 / 2$ wysokości przekroju wpływ na występujące $\mathrm{w}$ niej naprężenia powinny mieć jedynie naprężenia styczne $\tau$, co umożliwia zastosowanie modelu Volkersena do analizy połączenia klejonego [10,11,12]. Natomiast przy ustawieniu spoiny w 1/4 wysokości przekroju wpływ na wytężenie materiału mieć będą zarówno naprężenia styczne $\tau$, jak i naprężenia normalne $\sigma$.

\section{Model MES}

W celu wstępnej analizy zagadnienia pracy belki kompozytowej ze spoiną o charakterystyce sprężysto-idealnie plastycznej posłużono się Metodą Elementów Skończonych. Wykorzystując program Autodesk Simulation Mechanical 2016, wykonano łącznie cztery modele obliczeniowe, dwa z nich dla belki ze spoiną w $1 / 2$ wysokości przekroju oraz dwa dla belki ze spoiną w 1/4 wysokości przekroju. Schematy modeli przedstawiono na Rys. 4. Dla każdego schematu rozważono dwa rodzaje spoiny o grubości $t=1 \mathrm{~mm}$ oraz $t=0,5 \mathrm{~mm}$. Spoinę pogrubiono tak, żeby zachować stałą wysokość przekroju belki ( $h=$ const., Rys. 4$)$. 
a)

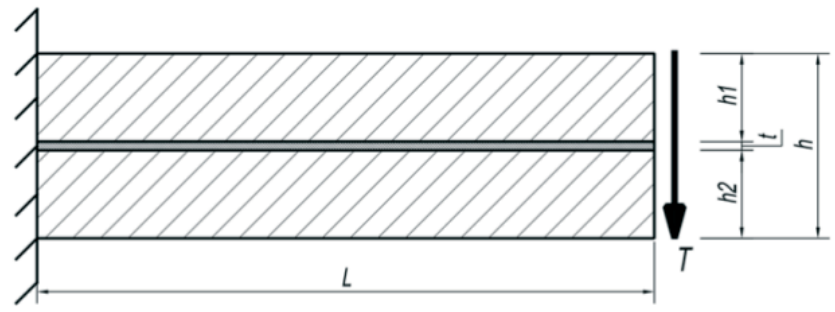

b)

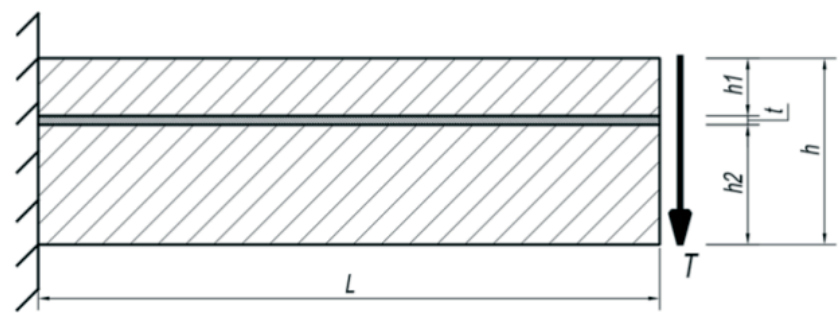

Rys. 4. Schematy modeli kompozytowej belki wspornikowej, a) spoina w środku, b) spoina w 1/4 wysokości

W każdym modelu zastosowano zagęszczenie siatki MES w obszarze spoiny, co pozwoliło ograniczyć różnice w wynikach obliczeń wynikające z rozmiarów siatki dyskretyzacyjnej. Spoinę modelowano elementami o kształcie kwadratowym (por. [2]) i wymiarze równym grubości rozpatrywanej spoiny (kolor czerwony), natomiast dla belek stosowano zasadę dwukrotnego powiększania elementu w kierunku od spoiny stosując trójkątne elementy pośrednie (kolor zielony). Zasadę tworzenia siatki MES przyjęto podobnie jak w pracy [9] i przedstawiono ją na Rys. 4a.

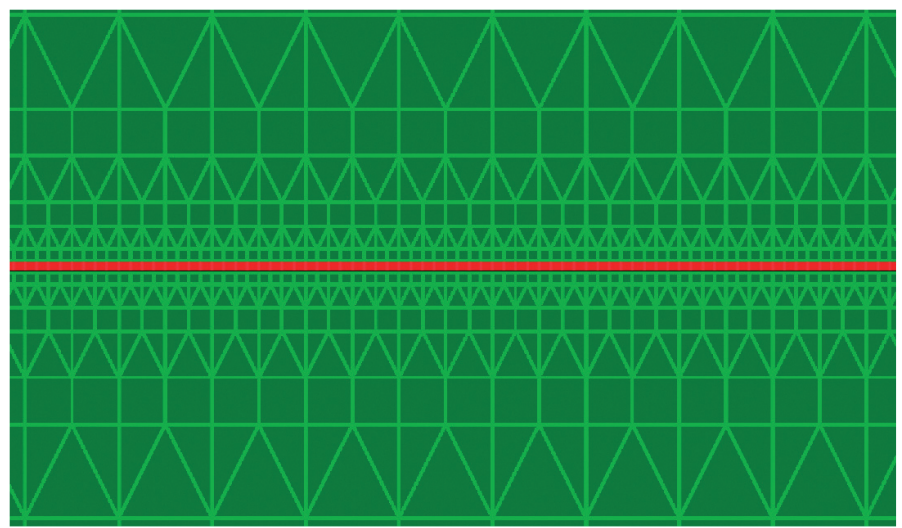

Rys. 4a. Siatka MES w pobliżu spoiny

Założono wykonanie obu belek z takiego samego materiału o charakterystyce liniowo-sprężystej, natomiast spoiny z materiału słabszego sprężysto-idealnie plastycznego, co zostało pokazane na Rys.5. Parametry materiałowe zamieszczono w Tabeli 1. Wszystkie elementy skończone zdefiniowano jako elementy powłokowe (shell) w systemie Autodesk Symulation Mechanical 2016, co umożliwiło wykorzystanie sprężysto-plastycznej charakterystyki materiału [6]. 

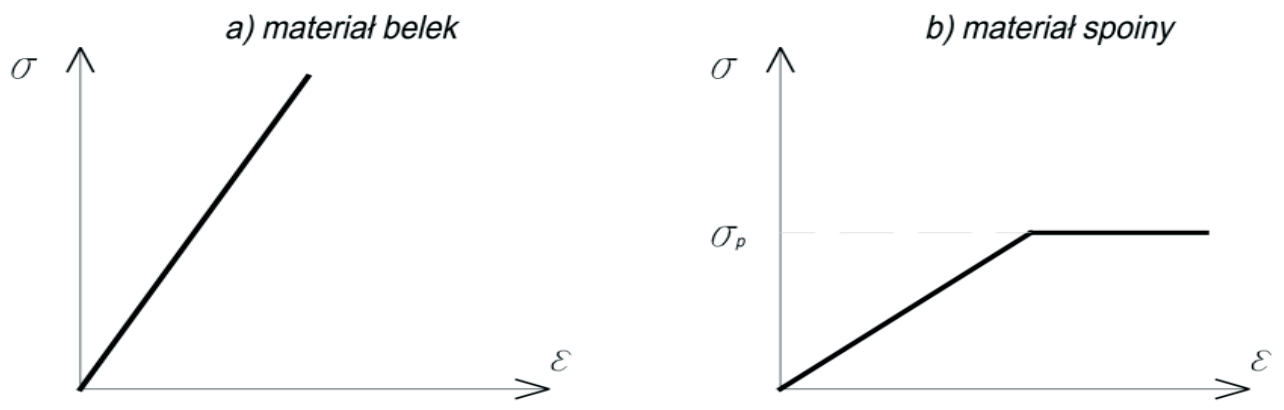

Rys. 5. Zależność $\sigma-\varepsilon$ materiałów belki kompozytowej

Tabela 1. Parametry materiałowe modelu

\begin{tabular}{lcc}
\hline Składowa kompozytu & Belka & Spoina \\
\hline Materiał & Drewno & Klej epoksydowy \\
\hline Moduł Younga, E $[\mathrm{GPa}]$ & 20,0 & 2,0 \\
\hline Współczynnik Poissona, $v$ & 0,25 & 0,35 \\
\hline Granica plastyczności, $\sigma_{\mathrm{p}}[\mathrm{MPa}]$ & - & 5,0 \\
\hline
\end{tabular}

Sposób modelowania obciążenia kompozytu nie był oczywisty. O ile w modelu jednowymiarowym możliwe jest przyłożenie siły skupionej do swobodnego końca belki, tak już w modelu dwuwymiarowym przyłożenie siły w punkcie na górze belki powodowałby znaczną koncentrację naprężeń. Dlatego też, w rozważanym przypadku zastosowano równomierne rozłożenie siły pionowej na całym przekroju końca swobodnego belki. Obciążenie zadano jako ciśnienie krawędziowe działające pionowo. Dla wszystkich modeli zastosowano taki sam przebieg przyrostu obciążenia w celu porównania otrzymanych wyników. Zamocowanie belki wykonano poprzez blokadę wszystkich składowych przemieszczenia i obrotu węzłów. Modele obliczeniowe belki wykonane podobnie jak w pracy [7] przedstawiono na Rys. 6.

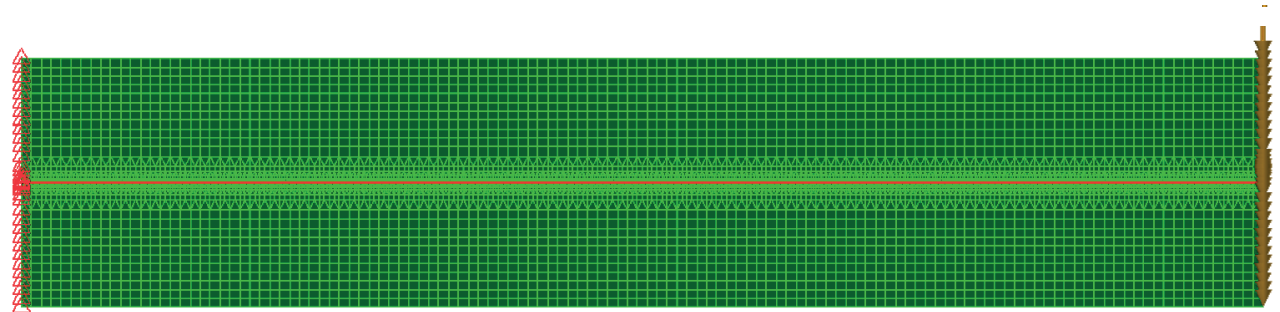

a)

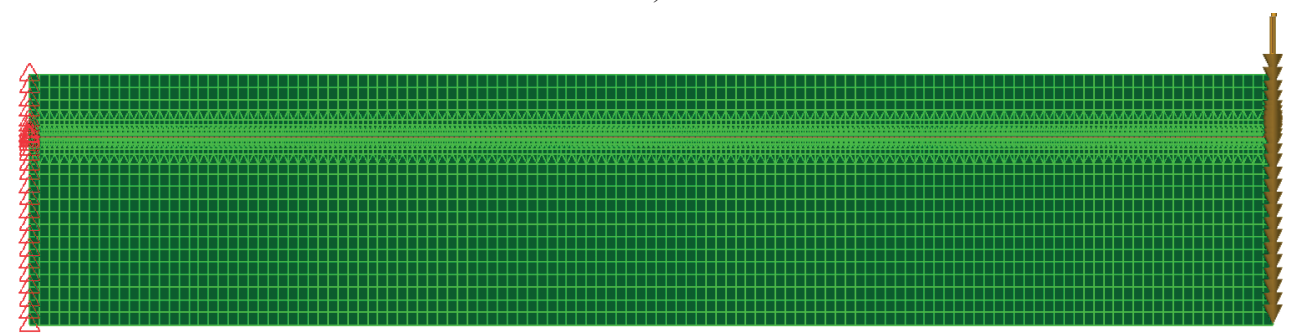

b)

Rys. 6. Modele obliczeniowe belki wspornikowej 


\section{Wyniki analiz numerycznych}

Obliczenia MES przeprowadzono dla czterech modeli z różną grubością i rozmieszczeniem spoiny w przekroju. Przeanalizowano wpływ uplastycznienia spoiny na przemieszczenie swobodnego końca belki, oraz zbadano przebieg tego uplastycznienia w zależności od położenia względem długości belki.

Analizę rozpoczęto od belki kompozytowej ze spoiną w 1/2 wysokości przekroju. Na Rys. 7 przedstawiono mapy naprężeń na początku i na końcu procesu obciążania belki, który zakończono w momencie całkowitego uplastycznienia się spoiny. Wyraźnie widoczny jest początek oddzielnej pracy belek przy całkowitym uplastycznieniu spoiny - wzrost naprężeń przy utwierdzeniu w miejscu połączenia belek spoiną.

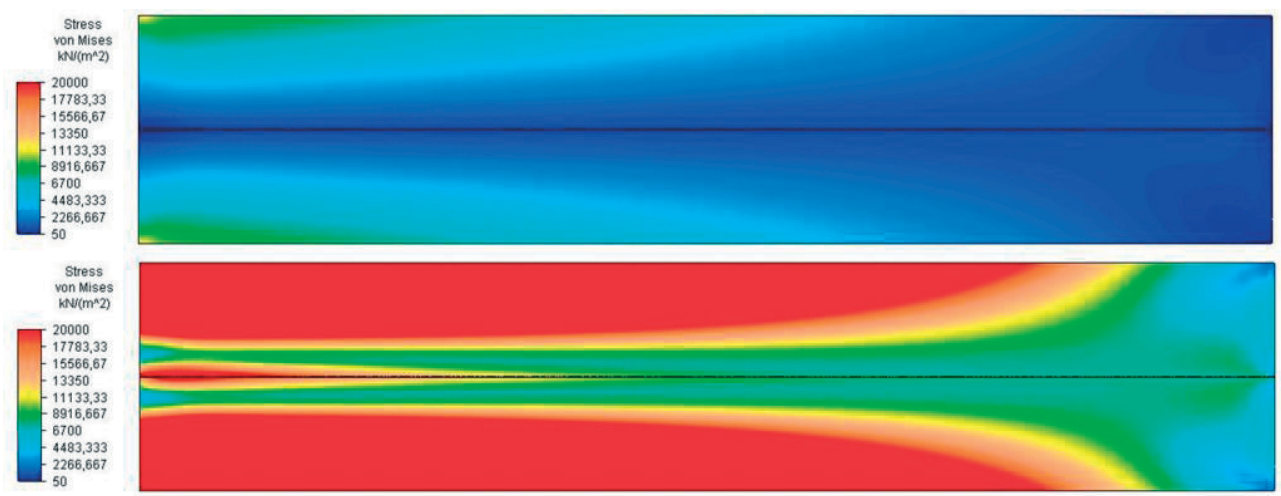

Rys. 7. Mapy naprężeń w belce kompozytowej ze spoiną w $1 / 2$ wysokości przekroju na początku i na końcu procesu obciążania

Kolejnym krokiem było sprawdzenie wpływu uplastycznienia spoiny na przemieszczenie swobodnego końca belki. Wykres zależności przemieszczenia od przyrostu siły $T$ przedstawiono na Rys. 8.

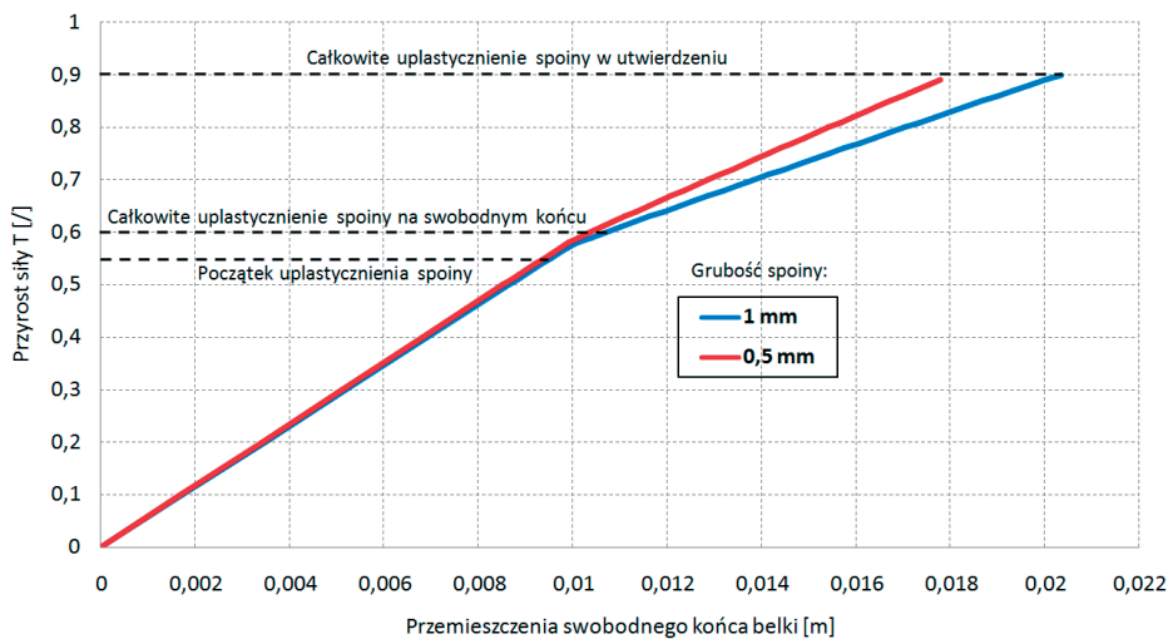

Rys. 8. Zależność przemieszczenie końca belki - przyrost siły $T$ dla spoiny o różnej grubości, wykonanej w $1 / 2$ wysokości przekroju 
Z powyższego wykresu wynika, że grubość spoiny na początku jej uplastycznienia nie wpływa na całkowite ugięcie belki. Różnica zaczyna pojawiać się dopiero w momencie uplastycznienia na swobodnym końcu i zwiększa się wraz z jego postępowaniem w kierunku utwierdzenia. Dokładną analizę przebiegu uplastycznienia przedstawiono na Rys. 9.

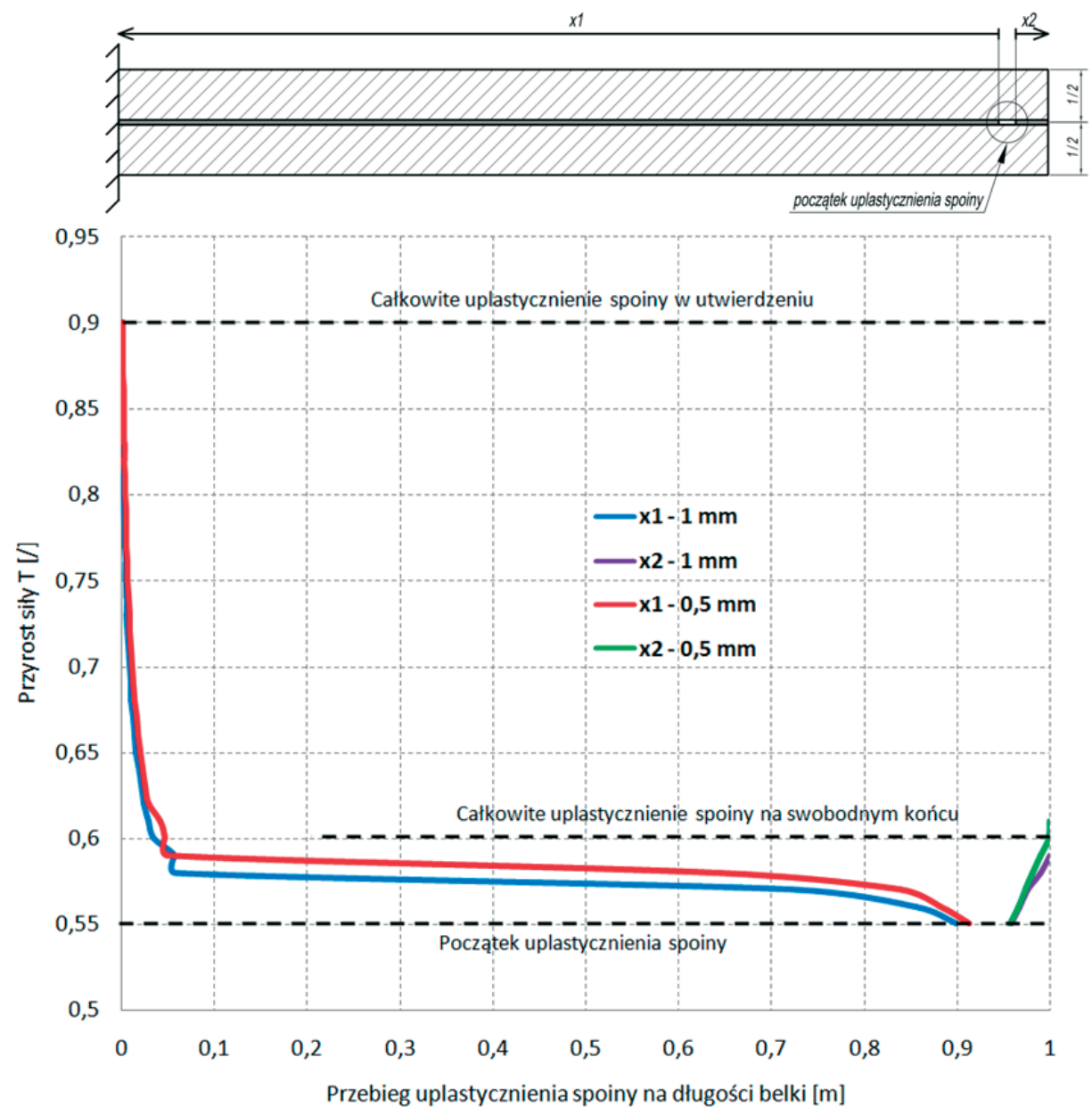

Rys. 9. Analiza przebiegu uplastycznienia spoiny dla belki ze spoiną w $1 / 2$ wysokości przekroju

Dla rozważanego przypadku uplastycznienie zaczyna się blisko swobodnego końca belki. Można też zauważyć, że we wstępnej fazie uplastycznienie cieńszej spoiny przebiega przy większym obciążeniu niż spoiny o większej grubości, jednak całkowite uplastycznienie następuje prawie w tym samym momencie.

W celu porównania naprężeń otrzymanych metodą numeryczną (MES) z naprężeniami zredukowanymi obliczonymi na podstawie równania (7), wyznaczono w miejscu styku spoiny z belką 101 punktów, w rozstawie co $1 \mathrm{~cm}$, dla których odczytano naprężenia w zależności od przyrostu siły $T(\Delta)$ (Rys. 10a). Następnie wykonano wykres powierzchniowy naprężeń od początku procesu obciążania belki do momentu całkowitego uplastycznienia spoiny (Rys. 10b). Wyraźnie widać, że wyniki teoretyczne można porównywać do numerycznych jedynie w zakresie liniowo-sprężystym (Rys. 11). 
a)

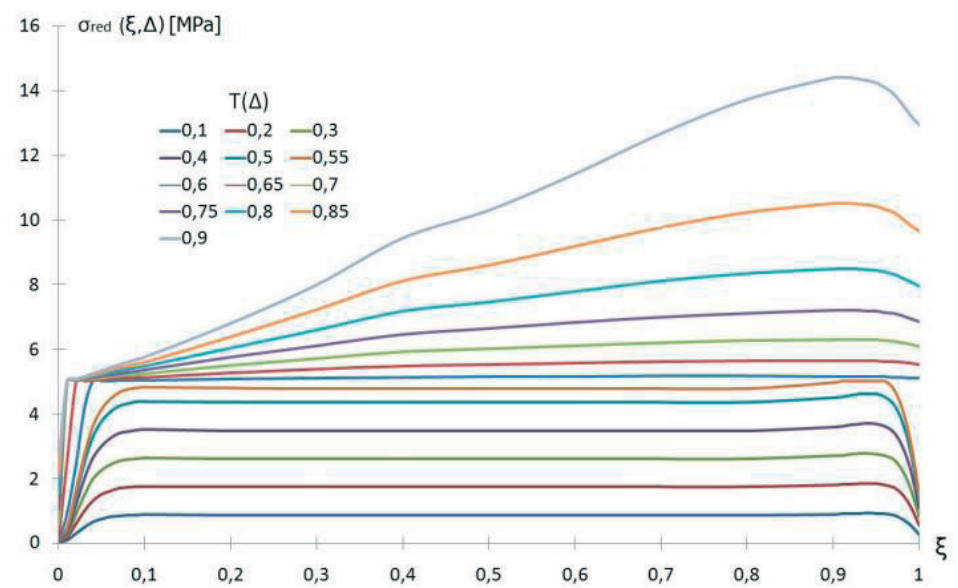

b)

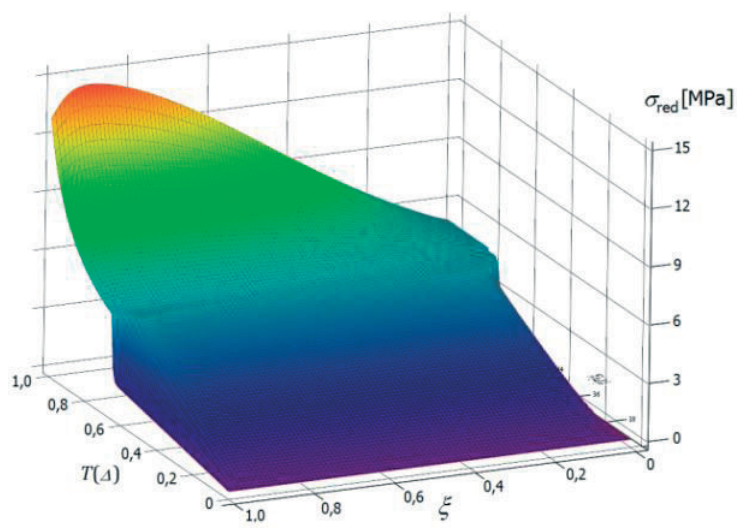

Rys. 10. Naprężenia na styku spoina - belka w zależności od przyrostu siły $T$ wyznaczone analizą MES, a) wykres liniowy, b) wykres powierzchniowy

Po uplastycznieniu spoiny przebieg naprężeń ulega wyraźnej zmianie, co jest widoczne na Rys. 10. Opisanie występujących tu zależności przy pomocy formuł otrzymanych metodami analitycznymi nie będzie rozważane w tym artykule.

Porównując wykresy z Rys. 11 a) i Rys. 11 b) można zauważyć, że dla punktów spoiny o współrzędnych $\xi$ zawierających się w przedziale $(0,05 \div 0,95)$, wykresy są do siebie zbliżone, natomiast przy zamocowaniu $(\xi=0)$ i swobodnym końcu $(\xi=1)$ - naprężenia w spoinie znacznie się zmniejszają co spowodowane jest znaczną różnicą warunków brzegowych w modelu 2D (MES) i analitycznym jednowymiarowym modelem belkowym. Podobne efekty brzegowego zaburzenia propagacji szczeliny w czasie delaminacji obserwowano w modelu wykorzystującym materiał sprężysto kruchy jako materiał spoiny, który analizowany był w pracy Z. Mroza i J. Podgórskiego [5]. Szczelina powstająca podczas delaminacji modelowana tam była metodą usuwania zniszczonych elementów z siatki MES w kolejnych krokach analizy numerycznej [8].

Kolejnym etapem była analiza kompozytu ze spoiną usytuowaną w 1/4 wysokości przekroju. Tak jak w poprzedniej analizie na Rys. 12, przedstawiono mapy naprężeń na początku oraz przy końcu procesu obciążania. W tym przypadku nie jest widoczny wyraźny wzrost naprężeń po uplastycznieniu spoiny ze względu na większy przekrój belki dolnej. 
a)

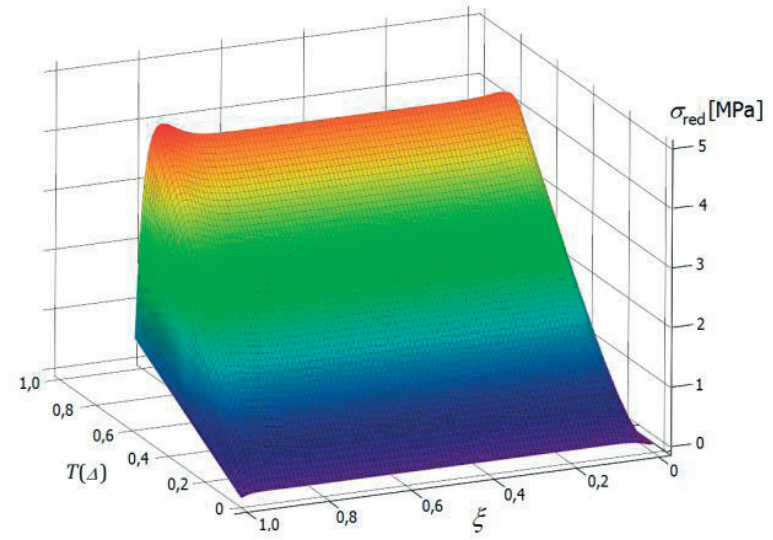

b)

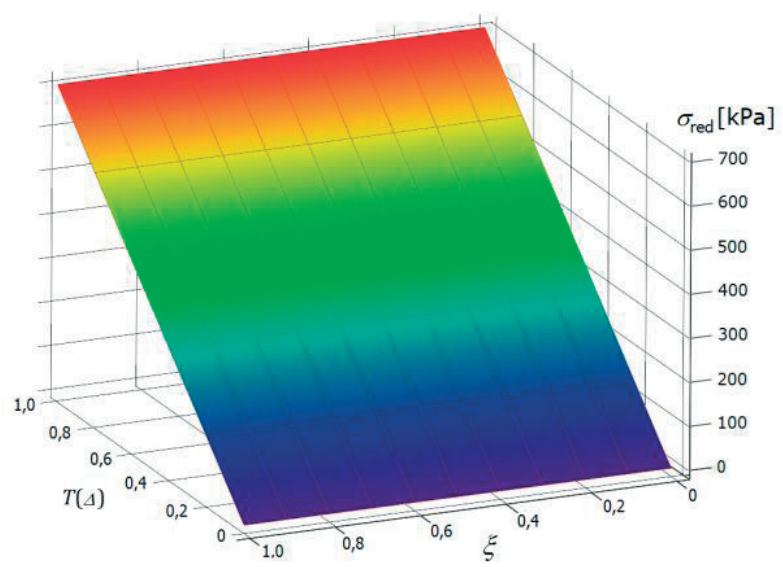

Rys. 11. Wykres funkcji naprężeń dla spoiny w $1 / 2$ wysokości przekroju dla liniowo-sprężystego zakresu pracy spoiny a) analiza MES, b) wyniki otrzymane analitycznie (równ. 10)

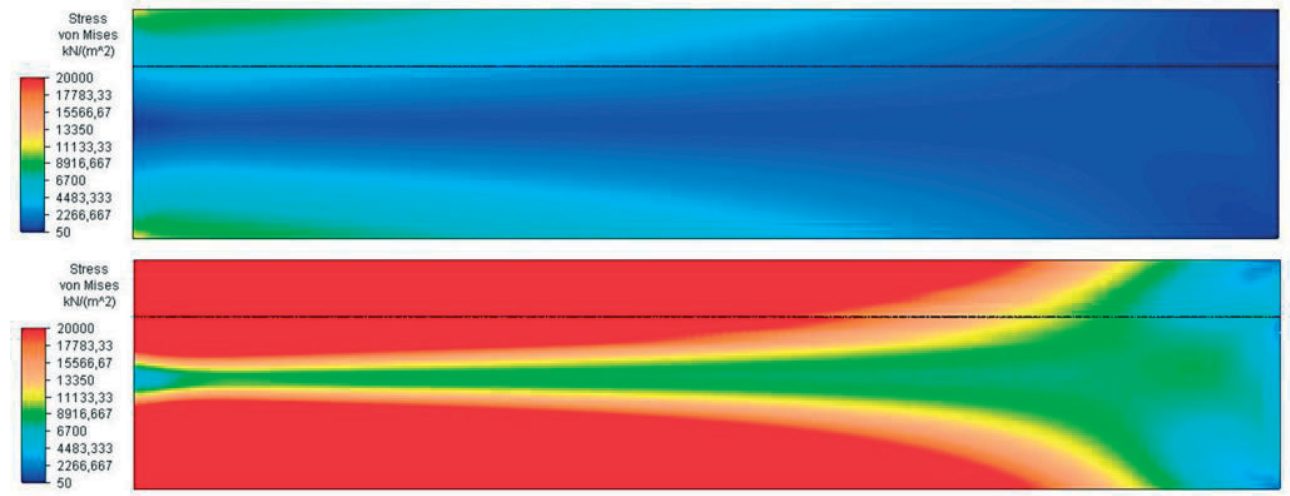

Rys. 12. Mapy naprężeń w belce kompozytowej ze spoiną w 1/4 wysokości przekroju na początku i na końcu procesu obciążania 
Wpływ uplastycznienia spoiny na przemieszczenie swobodnego końca belki przedstawiono na Rys. 13, natomiast jego przebieg znajduje się na Rys. 14.

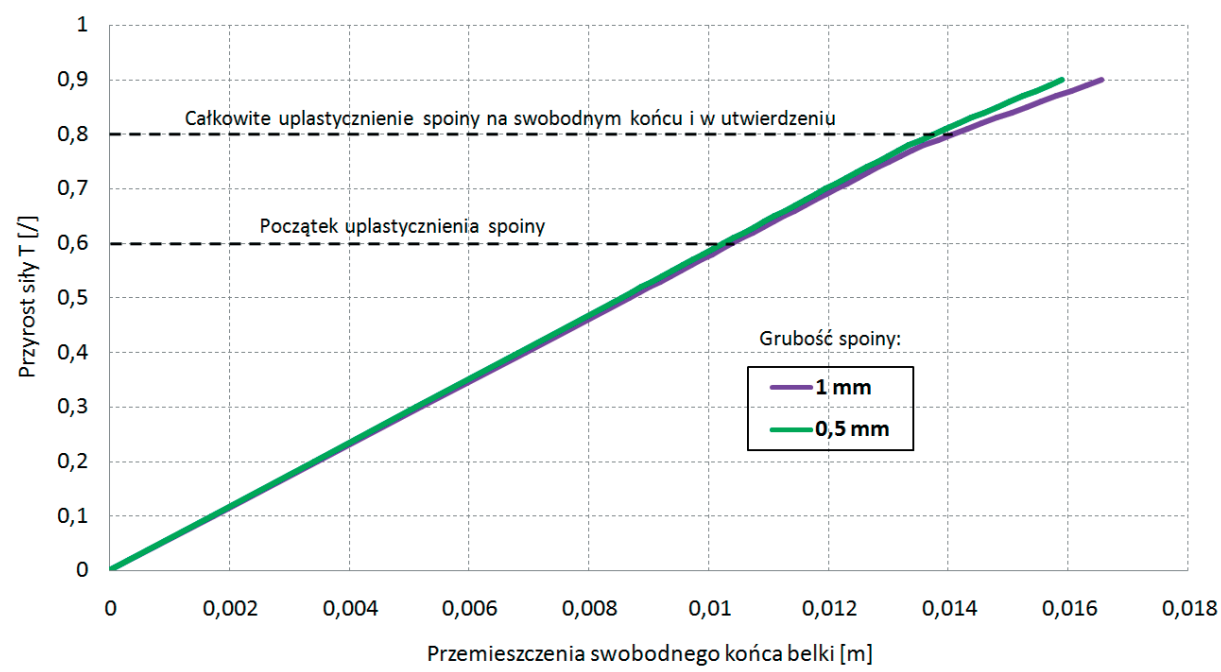

Rys. 13. Zależność przemieszczenie końca belki - przyrost siły $T$ dla spoiny o różnej grubości, wykonanej w $1 / 4$ wysokości przekroju
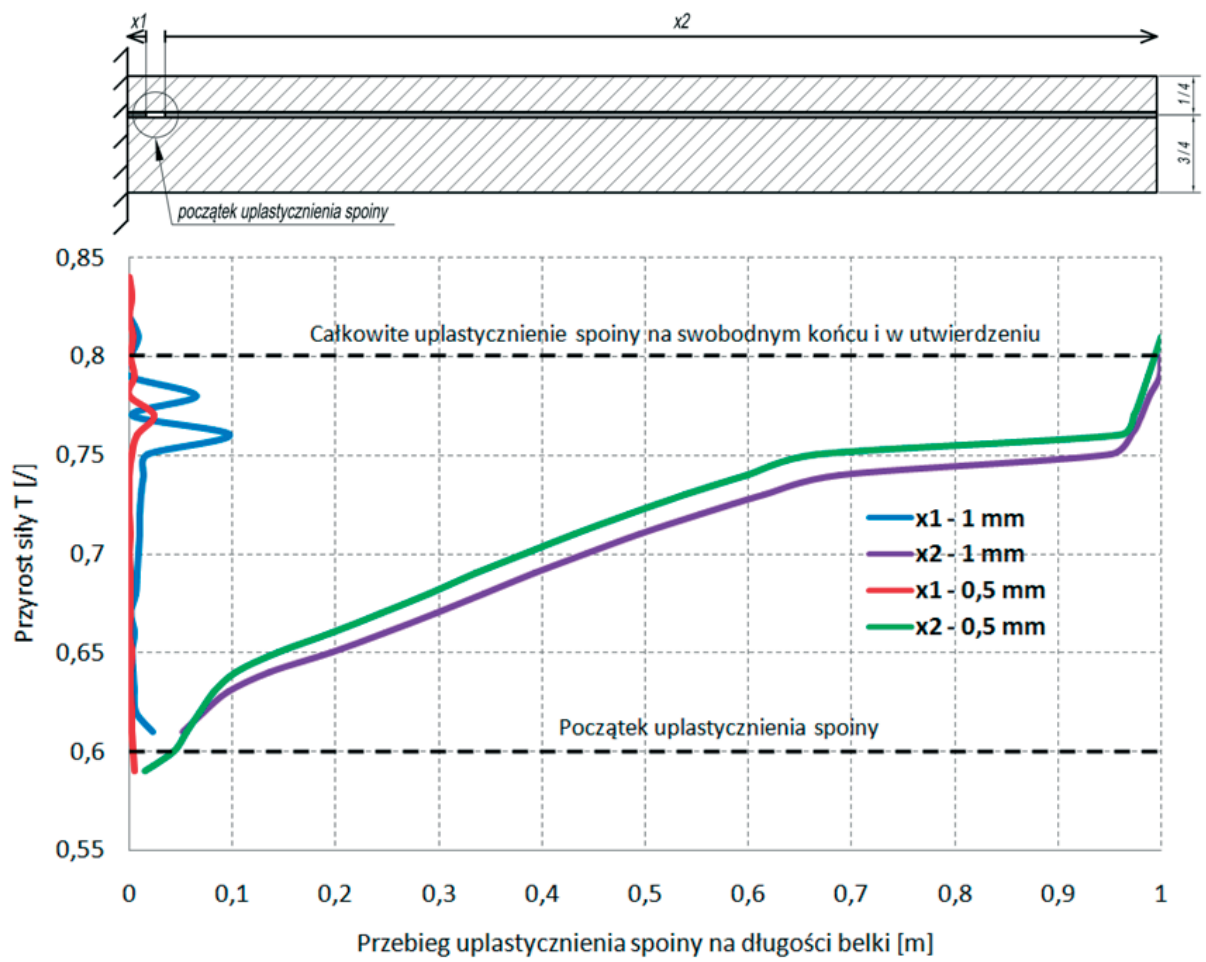

Rys. 14. Analiza przebiegu uplastycznienia spoiny dla belki ze spoiną w 1/4 wysokości przekroju 
Wykresy naprężeń w zależności od przyrostu siły $T(\Delta)$ wyznaczono takim samym sposobem jak uprzednio dla spoiny w $1 / 2$ wysokości przekroju, zależności $\sigma_{\text {red }}$ od $\xi$ i $T$ przedstawiono na Rys. 15.

a)

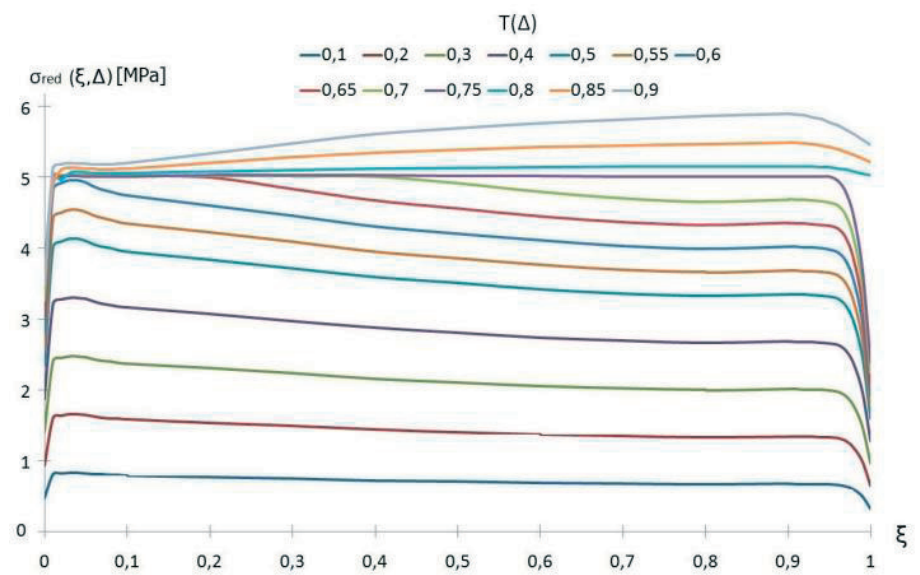

b)

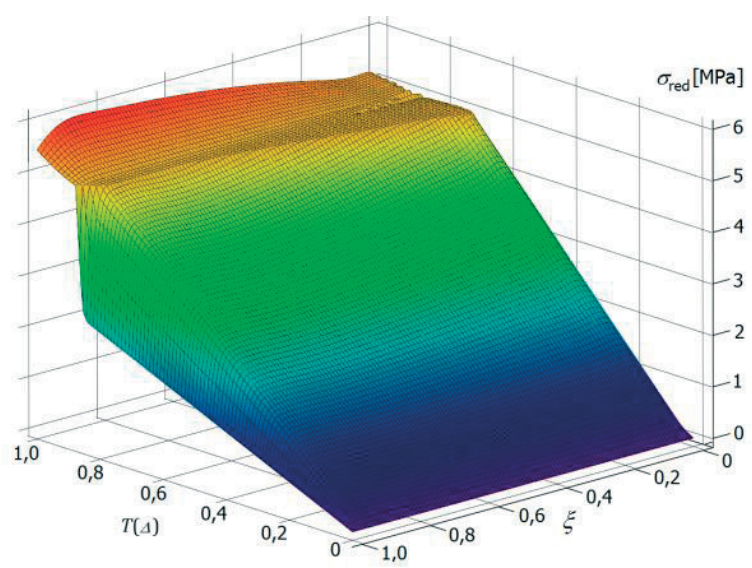

Rys. 15. Naprężenia na styku spoina - belka, w zależności od przyrostu siły $T$ wyznaczone na podstawie analizy MES, a) wykres liniowy, b) wykres powierzchniowy

Porównując wykresy z Rys. 16a i Rys. 16b można zauważyć tak jak poprzednio, że w punktach belki o współrzędnych $\xi$ zawierających się w przedziale od 0,05 do 0,95 wykresy są do siebie zbliżone, natomiast przy zamocowaniu i swobodnym końcu widoczne są znaczne różnice. Teoretycznie naprężenia na swobodnym końcu belki powinny zbliżać się do zera, natomiast w utwierdzeniu powinny być największe. Na wykresach otrzymanych z analiz numerycznych występują jednak pewne "załamania" w okolicy tych punktów co wywołane jest skomplikowaniem warunków brzegowych w modelu 2D, którym posłużono się w analizach MES. 
a)

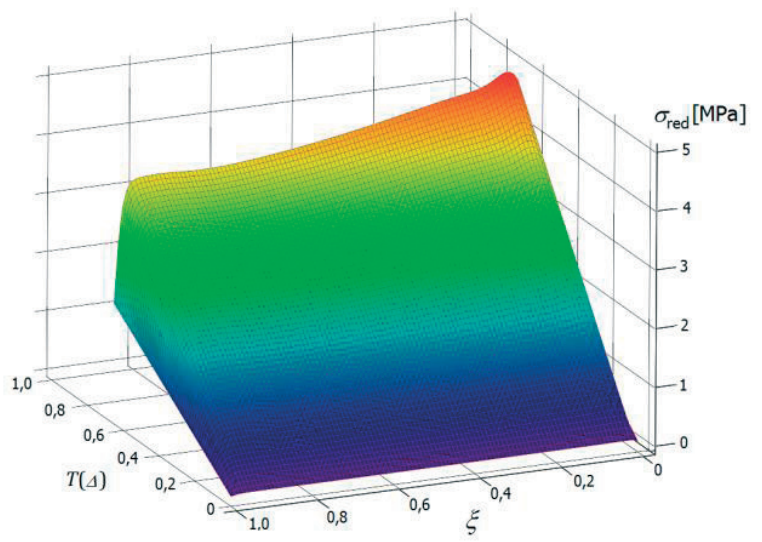

b)

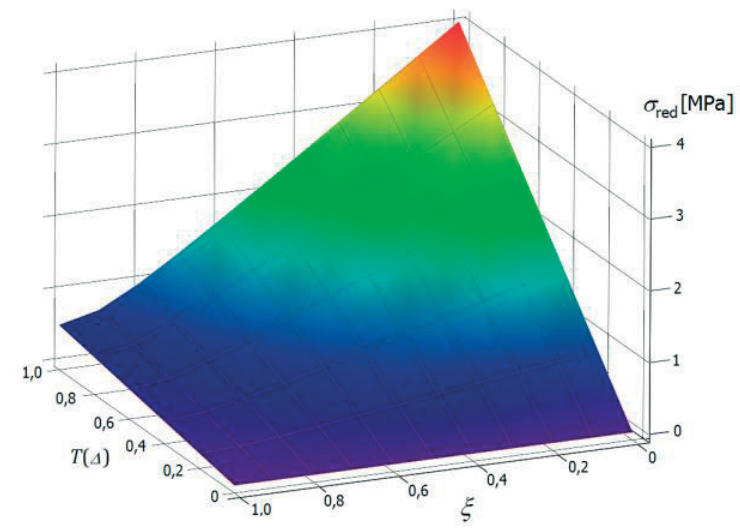

Rys. 16. Wykres powierzchniowy funkcji naprężeń dla spoiny w $1 / 4$ wysokości przekroju dla liniowosprężystego zakresu pracy spoiny - a) obliczenia MES, b) wyniki otrzymane analitycznie (równ. 10)

\section{Podsumowanie i wnioski}

Przedstawiona w pracy analiza pracy spoiny przeprowadzona $\mathrm{z}$ wykorzystaniem metody elementów skończonych i nieliniowego modelu materiału pokazała znaczące różnice wyników, które otrzymujemy stosując jednowymiarowe modele belkowe z zastosowaniem prostego założenia Volkersena, które przyjmuje tylko wpływ naprężeń stycznych na stan materiału spoiny. Zastosowany dwuwymiarowy model belki klejonej pozwolił dokładniej zbadać zachowanie się spoiny oraz początek procesu delaminacji w okolicach zamocowania i swobodnego końca belki. Ujawnił się tu wpływ warunków brzegowych a co za tym idzie, istotnie różny od liniowego rozkład pola naprężeń normalnych i parabolicznego dla naprężeń stycznych, na stan uplastycznienia materiału spoiny. Zastosowano hipotezę Hubera-Misesa do określenia granicy przejścia materiału spoiny w stan plastyczny co pokazało różnice w zachowaniu belki w zależności od położenia spoiny w przekroju poprzecznym.

Z przedstawionych analiz numerycznych wynika, że usytuowanie spoiny w $1 / 2$ przekroju po jej uplastycznieniu będzie powodowało początek procesu delaminacji belki kompozytowej od strony krawędzi swobodnej, natomiast przy ustawieniu spoiny w $1 / 4$ przekroju od strony utwierdzenia. Można też zauważyć, że początek uplastycznienia spoiny znajdującej się w połowie wysokości przekroju belki wystąpi przy mniejszym obciążeniu niż w przypadku spoiny znajdującej się powyżej osi obojętnej, co wywołane jest szybszym 
przyrostem naprężeń zredukowanych w spoinie po jej uplastycznieniu na końcu swobodnym. Na tej podstawie można stwierdzić, że najbardziej niekorzystne dla spoiny będzie ustawienie jej w osi obojętnej przekroju.

$\mathrm{Z}$ analizy wynika również, że zmienna grubość spoiny będzie powodowała różnice w wartości siły uplastyczniającej, co wymaga dalszych, dokładniejszych analiz, które są planowane w przyszłych pracach autorów.

\title{
Literatura
}

1. Białas M. Modeling of the damage development in contact layers, PHD Thesis, 2003, IFTR, Polish Academy of Sciences, Warsaw, Poland.

2. Godzimirski J., Tkaczuk S. Modelowanie spoin klejowych w obliczeniach MES. Biuletyn WAT, Vol. LIX, Nr 4, 2010.

3. Huber T. M. Stereomechanika techniczna, PWN, Warszawa, 1958.

4. Mróz Z., Mróz K.P. Analysis of delamination and damage growth in joined bi-layer systems, Geomechanics for Energy and the Environment 4 (2015) 4-28.

5. Mróz Z., Podgórski J. Analytical and numerical investigation of the adhesive layer in sandwich composites, 2nd International Conference on Mechanics of Composites, Porto, Portugal, July 11-14, 2016.

6. Piechnik S. Mechanika techniczna ciała stałego. Politechnika Krakowska, Kraków 2007.

7. Podgórski J., Błazik-Borowa E. Wprowadzenie do metody elementów skończonych w statyce konstrukcji inżynierskich, IZT, Lublin 2001.

8. Podgórski J. Influence Exerted by Strength Criterion on the Direction of Crack Propagation in the Elastic-Brittle Material, Journal of Mining Science 38(4) (2002) 374-380.

9. Rakowski G., Kacprzyk Z. Metoda Elementów Skończonych w mechanice konstrukcji. Oficyna Wydawnicza Politechniki Warszawskiej, Warszawa, 2005.

10. Rapp P. Mechanika połaczeń klejowych jako płaskie zadanie teorii sprężystości. Rozprawy nr 441, Wydawnictwo Politechniki Poznańskiej, Poznań, 2010.

11. Rodríguez R.Q. et al. Failure criteria for adhesively bonded joints, International Journal of Adhesion \& Adhesives 37 (2012) 26-36.

12. Vokersen O. Nietkraftverteiligung in zugbeanspruchten nietverbindungen mit konstanten Laschenquerschnitten, Luftfahrtforschung, 1938, 15-41.

\section{Analysis of cantilever composite beam work with regards to the different thickness and location of adhesive joint made of elastic-ideally plastic material}

\author{
Bartosz Kawecki, Jerzy Podgórski \\ Department of Structural Mechanics, Faculty of Civil Engineering and Architecture, \\ Lublin University of Technology,e-mail: b.kawecki@pollub.pl,j.podgorski@pollub.pl
}

\begin{abstract}
This paper presents the results of numerical analysis of the composite cantilever beam with elastic - perfectly plastic seam. Four numerical models using Finite Element Method was analysed for two different thickness and location of the adhesive bond. Determined the course of the plastic deformation of the seam and the influence of its thickness and location on the stress $i$ and the displacement of the beam free end.

Keywords: Composite beam, plastifying adhesive joint, joint plastifying course, joint thickness influence, joint location influence on stress distribution.
\end{abstract}

